\title{
Immune-triggering effect of the foodborne parasite Kudoa septempunctata through the C-type lectin Mincle in HT29 cells
}

\author{
Ji-Hun Shin ${ }^{1}$, Jung-Pyo Yang ${ }^{1}$, Seung-Hwan Seo ${ }^{1}$, Sang-Gyun Kim ${ }^{1}$, Eun-Min Kim ${ }^{2}$, Do-Won Ham ${ }^{1}$ E Eun-Hee Shin ${ }^{1,3, *}$ \\ ${ }^{1}$ Department of Tropical Medicine and Parasitology, Seoul National University College of Medicine and Institute of Endemic Diseases, \\ Seoul 03080, ${ }^{2}$ Department of Environmental Medical Biology, Yonsei University College of Medicine, Seoul 03722, ${ }^{3}$ Seoul National \\ University Bundang Hospital, Seongnam 13620, Korea
}

\begin{abstract}
Kudoa septempunctata is a myxozoan parasite that causes food poisoning in individuals consuming olive flounder. The present study aimed to investigate the currently insufficiently elucidated early molecular mechanisms of inflammatory responses in the intestine owing to parasite ingestion. After Kudoa spores were isolated from olive flounder, HT29 cells were exposed to spores identified to be alive using SYTO-9 and propidium iodide staining or to antigens of Kudoa spores (KsAg). IL-1 $\beta$, IL-8, TNF- $\alpha$ and NFKB1 expression and NF- $\mathrm{KB}$ activation were assessed using real-time PCR, cytokine array and westem blotting. The immunofluorescence of FITC-conjugated lectins, results of ligand binding assays using Mincle-Fc and IgG-Fc, CLEC4E expressions in response to $\mathrm{KsAg}$ stimulation, and Mincle-dependent $\mathrm{NF}-\mathrm{KB}$ activation were assessed to clarify the early immunetriggering mechanism. Inflammatory cytokines (IL-1 $\beta$, GM-CSF and TNF- $\alpha$ ), chemokines (IL-8, CCL2, CCL5 and CXCL1) and $\mathrm{NF}-\kappa \mathrm{B}$ activation (pNF- $\mathrm{k} / \mathrm{NF}-\kappa \mathrm{B}$ ) in HT29 cells increased following stimulation by KsAg. The immunofluorescence results of spores and lectins (concanavalin $\mathrm{A}$ and wheat germ agglutinin) suggested the importance of Mincle in molecular recognition between Kudoa spores and intestinal cells. Practically, data for Mincle-Fc and KsAg binding affinity, CLEC4E mRNA expression, Mincle immunofluorescence staining and hMincledependent NF-kB activation demonstrated the involvement of Mincle in the early immune-triggering mechanism. The present study newly elucidated that the molecular recognition and immune-triggering mechanism of $K$. septempunctata are associated with Mincle on human intestinal epithelial cells. [BMB Reports 2020; 53(9): 478-483]
\end{abstract}

*Corresponding author. Tel: +82-2-740-8344; E-mail: ehshin@snu. ac.kr

https://doi.org/10.5483/BMBRep.2020.53.9.079

Received 19 April 2020, Revised 23 May 2020, Accepted 7 August 2020

Keywords: Cell adhesion, C-type lectin Mincle, Innate immunity, Myxozoan parasite, Signal transduction

\section{INTRODUCTION}

Kudoa septempunctata (Myxosporea: Multivalvulida) is a novel myxosporean parasite that is primarily found in the trunk muscles of olive flounder (Paralichthys olivaceus) cultivated on Jeju Island in South Korea (1). This parasite is distinguished from the other members of the Kudoa spp. by the presence of irregular stellates, with the majority having seven unequal valves (6-7 valves allowed) in the apical view, as well as the formation of pseudocysts in myofibers without inflammatory reactions in trunk muscles; moreover, the infection is not macroscopically evident (1). K. septempunctata, which was first reported by Matsukane et al. (2010) as a new species of Myxosporea, infects humans who eat infected raw olive flounder and causes food poisoning (1-3).

Since the first description of $K$. septempunctata as the causative agent of a novel form of food poisoning in Japan, K. septempunctata has been recognised as a foodborne neglected pathogen causing food poisoning (1-4). However, the pathogenic mechanism of this parasite is not fully understood even though $K$. septempunctata is an important foodborne parasite. Several studies have debated the clinical significance of $K$. septempunctata and pathogenicity in in vivo test using mouse model (2-6). The pathogenicity of $K$. septempunctata was also controversial in in vitro assays using Kudoa spores (7-9). Ohnishi et al. insisted that the invasion of Caco-2 human intestinal cells by Kudoa sporoplasm induced damage through the loss of cell monolayer integrity via the elimination of transepithelial electrical resistance, suggesting their role as the causative agent of food poisoning in humans (7). Conversely, another study reported that infection of Caco- 2 cells by $K$. septempunctata spores did not result in inflammation (8), and another report found that $K$. septempunctata activated TLR-2expressing HEK293 cells and induced TNF- $\alpha$ production (9). As mentioned previously, the no definite conclusion can be drawn regarding the pathogenicity of $K$. septempunctata or the mechanism of food poisoning. To identify the pathogenic mechanism of $K$. septempunctata, it is necessary to identify the antigenicity of $K$. septempunctata spores. However, the immunetriggering mechanism of $K$. septempunctata infection has not yet been established. 
In a recent study, lectin histochemistry for K. septempunctata-infected olive flounder revealed the presence of various sugar residues ( $\mathrm{N}$-acetylglucosamine [GlcNAc], mannose, galactose and fucose) in Kudoa spores (10). Lectins are glycoproteins that specifically bind carbohydrate structures and potentially participate in biodefense mechanisms on the fish side (11). Among them, mannose, which has been known as a as a pathogen-associated molecular pattern (PAMP) found in fungi, is a cell wall component of microorganisms, and the corresponding lectin is the C-type lectin Mincle that senses infection through the recognition of PAMPs or various inflammatory tissue factors $(12,13)$. In addition, C-type lectins play an important role in presenting the antigens of microorganisms to macrophages and other scavenger and complement receptors in mammals including humans (12). Conversely, carbohydrate residues, the ligands of lectin receptors, localise widely on epithelial cells in flat fish, and they are important in protecting against infection by inhibiting the adhesion and penetration of pathogens (11). On this point, we postulated that the pathogenesis and immune response after $K$. septempunctata infection might be attributable to binding between carbohydrate residues on Kudoa spores and lectin receptors on the surface of human intestinal epithelial cells. To demonstrate this, we specifically focused on Mincle on human intestinal cells and performed in vitro studies to clarify the relationship between Mincle receptors and glycoconjugates, especially mannose, on Kudoa spores regarding the immune-triggering effect and production of inflammatory cytokines through PAMP-related immune responses.

\section{RESULTS}

\section{Increases in IL-8 and NFKB1 expression in K. septempunctata spores-infected HT29 cells}

We observed the morphological characteristics of Kudoa spores using bright field microscopy (Fig. 1A). Kudoa spores were detected using a commercial immunochromatography kit and conventional PCR in olive flounder muscle and the ST3 genotype was confirmed (Supplementary Fig. 1). The viability check of Kudoa spores was performed by SYTO ${ }^{\mathbb{R}} 9$ (green, alive) and propidium iodide (red, died) (Fig. 1B). The close binding between PKH67-labelled Kudoa spores and HT29 cells was observed when they were co-cultured for $4 \mathrm{~h}$; the red arrow points to the polar filament that connects $K$. septempunctata and cell surface (Fig. 1C). To investigate the immune-triggering effect of Kudoa spores on intestinal epithelial cells, we examined the mRNA expression of IL-8 and NFKB1, which are related to the inflammatory response, and the results revealed gradual concentration-dependent increases in their mRNA expression at multiplicity of infection (MOI) of 2, 5 and 10 during $24 \mathrm{~h}$ of culture $(* \mathrm{P}<0.05$, Fig. 1D and 1E).
A

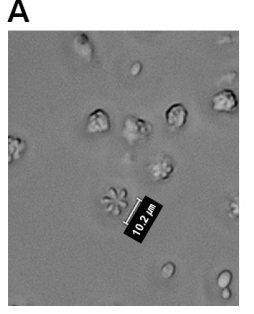

B

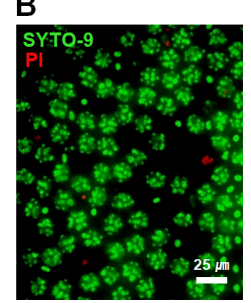

C
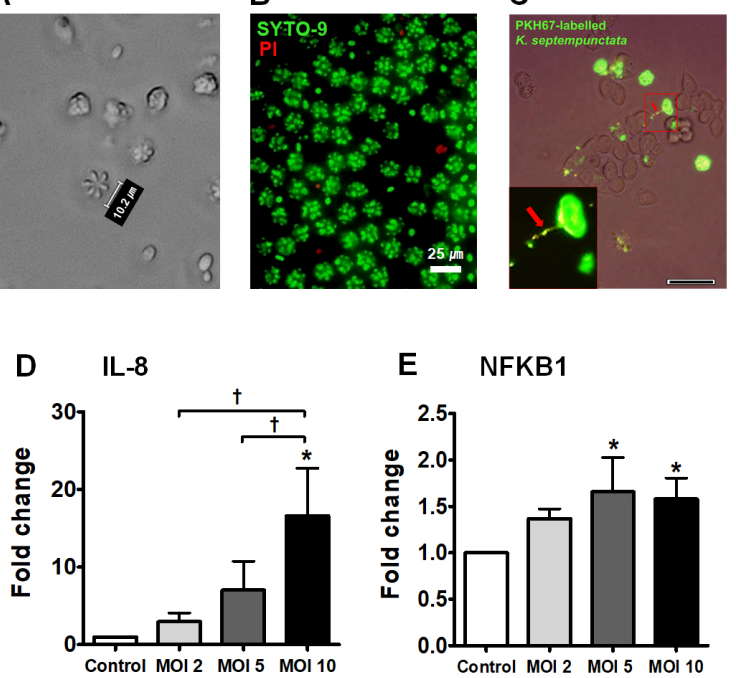

E NFKB1

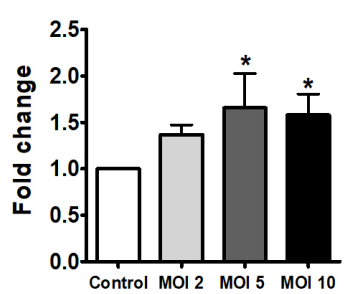

Fig. 1. Increase in IL-8 and NFKB1 levels in K. septempunctata sporeinfected HT29 cells. (A) Morphology of Kudoa spores under bright field microscope. (B) The viability of Kudoa spores. (C) PKH67-labelled Kudoa spores attached to HT29 cells. Red arrow designates polar filament. (D) IL-8 mRNA levels. (E) NFKB1 mRNA levels. ${ }^{*} \mathrm{~A}$ significant difference compared with control $(\mathrm{P}<0.05)$. ${ }^{\dagger} \mathrm{A}$ significant difference among the experimental groups $(P<0.05)$.

\section{Induction of inflammatory cytokines and NF-kB after stimulation with $\mathrm{KsAg}$ in $\mathrm{HT} 29$ cells}

To investigate the immune-triggering effect of KsAg on HT29 cells, we examined the mRNA levels (fold change) of IL-1 $\beta$, IL-8, and TNF- $\alpha$ in HT29 cells stimulated with $50 \mu \mathrm{g} / \mathrm{ml} \mathrm{KsAg}$ for $24 \mathrm{~h}$. KsAg stimulation significantly increased the mRNA levels of these inflammatory cytokines compared with the control levels ( $* \mathrm{P}<0.05$, Fig. $2 \mathrm{~A})$. In addition, multiplexed protein detection of inflammatory cytokines and chemokines after KsAg stimulation revealed increased levels of IL-8, TNF- $\alpha$, and several chemokines (CCL5, CXCL1, and GM-CSF) that participate in the chemoattraction and activation of leucocytes (Fig. 2B). Among them, the levels of TNF- $\alpha$ and CXCL1 in particular were significantly increased ( ${ }^{\mathrm{P}}<0.05$, Fig. $2 \mathrm{~B}$ ). The phosphorylation of NF- $\kappa \mathrm{B}$, which is a transcription factor of inflammatory cytokines, was significantly increased following KsAg stimulation $(* \mathrm{P}<0.05$, Fig. $2 \mathrm{C})$.

\section{FITC-lectin staining of glycoconjugates on the surface of Kudoa spores}

The aforementioned results illustrated the possibility that Kudoa spores can induce innate immunity through pattern recognition. In this respect, we investigated the possibility of lectin binding to Kudoa spores using FITC-conjugated lectins (BSL-I, ConA, WGA, UEA-I) (Fig. 3). Because Kudoa infects intestinal epithelial cells, lectin recognition, which allows pattern recognition as the first line of defence in the pre-immune host, may 
A
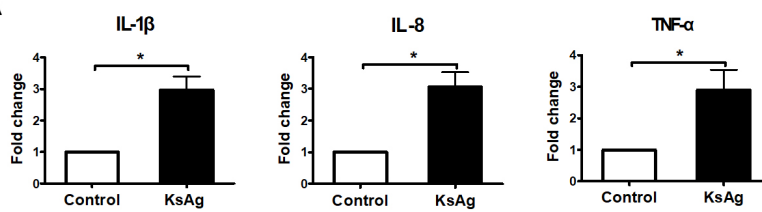

B

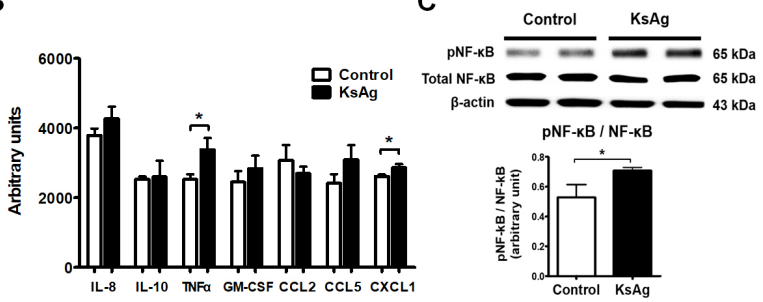

Fig. 2. Induction of inflammatory cytokines and NF- $\kappa B$ activation in KsAg-stimulated HT29 cells. (A) mRNA expression of inflammatory cytokines in HT29 cells. Data are presented as the mean \pm $\mathrm{SD}$ of fold changes for each cytokine versus the control. (B) Cyto-

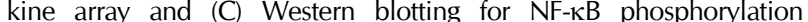
and the expression ratio of phospho-NF- $\kappa$ B/total phospho-NF- $\kappa B$ ( $n$ $=4)$. $* P<0.05$
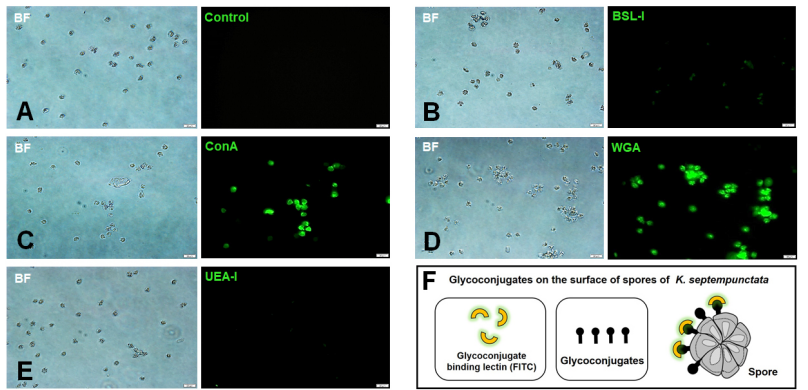

Fig. 3. FITC-conjugated lectin staining for Kudoa septempunctata spores. (A-E) Binding between the spores and lectins. (A) Control; (B) FITC-BSL-I; (C) FITC-ConA; (D) FITC-WGA; (E) FITC-UEA-I. Magnification is $\times 400$. Scale bar is $20 \mu \mathrm{m}$. (F) Schematic view of the binding between glycoconjugates of $K$. septempunctata spores and FITCconjugated lectins.

play a role in the pattern recognition of $\mathrm{KsAg}$ for inducing innate immunity after infection. FITC-conjugated BSL-I (major affinity for terminal $\alpha$-D-galactosyl residues), Con A (major affinity for $\alpha$-D-mannosyl and $\alpha$-D-glucosyl residues), WGA (Glc NAc residues) and UEA-I ( $\alpha$-linked fucose residues) were stained with Kudoa spores to confirm the glycoconjugate moiety on the spore surface (Fig. 3). The result demonstrated that Con A and WGA bind to Kudoa spores (Fig. $3 \mathrm{C}$ and 3D), whereas BSL-I and UEA-I did not bind (Fig. 3B and 3E). Fig. 3F shows a schematic diagram of the molecular mechanism for binding between FITC-lectins and spores. This result suggests that glycoconjugate moieties such as mannose, glucose and GlcNAc
A
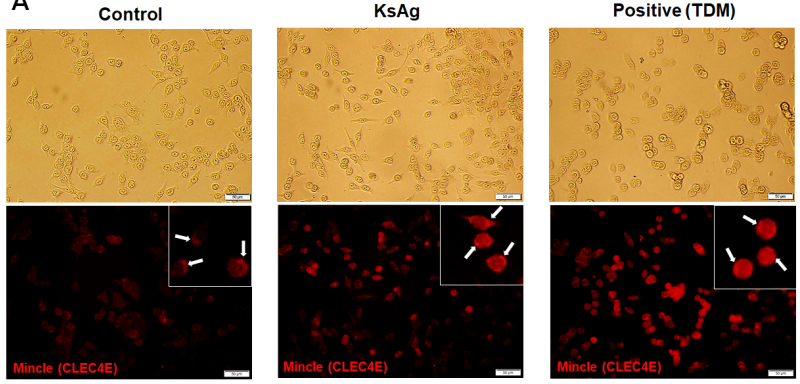

B

CLEC4E

C

믐 IING-Fc

D Reporter cell assay
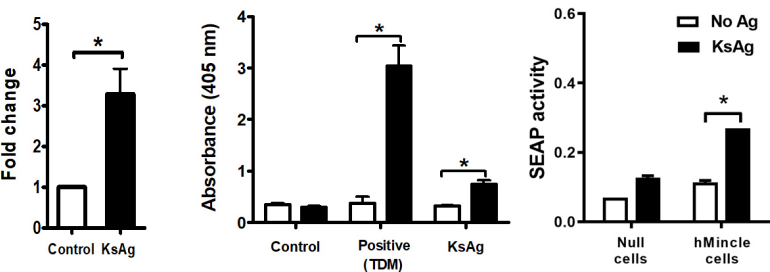

Fig. 4. KsAg-Mincle-Fc fusion protein binding and subsequent Mincledependent SEAP release. (A) Immunofluorescence image of Mincle protein. White arrows indicate Mincle expression on the cells. (B) CLEC4E mRNA expression ( ${ }^{\mathrm{P}}<0.05$ ). (C) KsAg-Mincle-Fc fusion protein binding. Trehalose-6, 6'-dimycolate (TDM, a well-known Mincle ligand) was used as a positive control (*P $<0.05)$. (D) Difference of NF- $\kappa B$-induced SEAP activity between HEK-Blue ${ }^{\mathrm{TM}}$ hMincle and HEK-Blue ${ }^{\mathrm{TM}}$ Null1-v cells (parental cell line) with and without KsAg treatment. Data are expressed as the mean \pm SD. There was a significant difference between HEK-Blue ${ }^{\mathrm{TM}}$ hMincle cells that were treated with KsAg and those that were untreated ( $\left.{ }^{*} P<0.001\right)$.

residues on spores might be responsible for the binding to human intestinal cells.

\section{KsAg stimulation in HT29 cells induced elevated CLEC4E levels and Mincle-dependent NF- $\kappa B$ activation}

Mincle protein expression was remarkably increased in HT29 cells after KsAg stimulation, similar to that observed after stimulation with TDM (Fig. 4A). Red fluorescence staining in HT29 cells denoted the presence of Mincle proteins (arrow) on the cell surface (Fig. 4A). At this time, the mRNA expression of CLEC4E (gene encoding Mincle protein) significantly increased by 3.3-fold compared with the control level $(* P<0.05$, Fig. $4 \mathrm{~B})$. Next, we investigated whether KsAg can bind to Mincle (Fig. 4C). For this, we investigated the binding affinity of ligands using Mincle-Fc and IgG-Fc antibodies on TDM- or KsAg-captured ELISA plates. TDM, a well-known Mincle ligand, was bound by Mincle-Fc antibody, leading to a remarkable increase in the absorbance level (at $405 \mathrm{~nm})(* \mathrm{P}<0.05)$; similarly, the binding affinity between $\mathrm{KsAg}$ and Mincle-Fc antibody was significantly increased compared with the negative control level (IgG-Fc) $\left({ }^{*} \mathrm{P}<0.05\right.$, Fig. 4C). Further study demonstrated NF- $\kappa B$ activation through Mincle following infection by K. septempunctata (Fig. 4D). To assess this, we used 
the genetically engineered cell lines HEK-Blue ${ }^{\mathrm{TM}} \mathrm{hMincle}$ and HEK-Blue ${ }^{\mathrm{TM}}$ Null1-v cells (parental cell line). When HEK-Blue Null1-v cells and HEK-Blue hMincle were treated with $20 \mu \mathrm{g} /$ $\mathrm{ml} \mathrm{KsAg}$, the mean secreted embryonic alkaline phosphatase (SEAP) activity increased from $0.07 \pm 0.000$ to $0.11 \pm 0.005$ in HEK-Blue Null1-v cells and from $0.12 \pm 0.005$ to $0.27 \pm$ 0.000 in HEK-Blue hMincle cells ( $* P<0.001$, Fig. 4D). These results demonstrated that $K$. septempunctata stimulates inflammatory innate immunity through Mincle in human intestinal epithelial cells following infection. Furthermore, we also demonstrated that KsAg increased NF- $\mathrm{KB}$ activation, and the induction of NF-KB expression by KsAg was the result of recognition by Mincle.

\section{DISCUSSION}

In the present study, we attempted to assess the mechanism triggering early immune response in the intestine during Kudoa infection. Because early investigators reporting on the pathogenicity of Kudoa conducted experiments under different conditions that made the experimental interpretation difficult such as different Kudoa genotypes and contamination by other bacteria associated with food poisoning, it has been difficult to understand the immune response associated with Kudoa infection (14-16). Moreover, epidemiological studies of food poisoning in humans who consumed raw olive flounder did not clearly prove that food poisoning was not caused by other pathogens, and it is not feasible to accept the results of case studies with no control group (16). In this regard, it is necessary to investigate the inflammatory response and innate immunetriggering mechanism using $\mathrm{KsAg}$ to identify the correlation between ST3 K. septempunctata infection and intestinal inflammatory responses and aetiology.

The inflammatory responses observed in this study firmly indicate the possibility that Kudoa infection or KsAg treatment can induce inflammatory reactions in HT29 cells. In contrast, previous studies using other cell lines such as Caco-2 human intestinal and RAW264.7 macrophage-like cells did not clearly indicate the cytotoxicity of Kudoa $(8,9)$. Meanwhile, other effort to determine the pathogenicity of $K$. septempunctata infection focused on the loss of cell monolayer integrity in intestinal cells after infection (7). Intracellular invasion by $K$. septempunctata sporoplasm, which is released from spores, plays an important role in mediating the toxicity of the parasite in Caco-2 cells (7). From the results of previous studies, although K. septempunctata can infect intestinal cells, there was no definitive evidence of a relevant inflammatory immune response. Thus, the present study focused on the immune-triggering mechanism inducing inflammatory responses in the early phase of $K$. septempunctata infection, observing the importance of binding between glycoconjugates on Kudoa spores and Mincle on human intestinal cells in triggering inflammatory responses through PAMP. These glycoconjugates can bind to mannose receptors, facilitating their involvement in PAMP recognition- related immune responses (17).

Moreover, our findings raise the possibility of an interaction between Mincle and TLR2 signalling in the production of inflammatory cytokines based on a previous in vitro study of Kudoa (9). Although only limited early stage studies have been conducted, Kudoa appears to stimulate macrophages through TLR2 signalling, and TLR2 and Mincle can cooperatively sense pathogens through the cooperative action of both receptors $(9$, 18). Most importantly, Mincle-mediated innate immunity can induce sustained inflammatory responses, especially those involving IL- 1 and TNF- $\alpha$, and it can promote allergic responses $(12,19)$. In a study, BALB/c mice fed Kudoa sp.-infected fish extract exhibited increases specific IgE levels in their sera (20). In addition, 4 of 15 patients with gastrointestinal and/or allergic symptoms related to fish ingestion had positive results for the skin prick test using Kudoa antigens (21). A recent study found that $\mathrm{KsAg}$ induced the production of IgE in BALB/c mice, and the authors insisted that KsAg can be an allergen (22). This result is helpful for understanding the contribution of allergy to the foodborne illness caused by $K$. septempunctata, which has a short lag phase of illness (1-12 h) (22).

There is some evidence that $K$. septempunctata infection may induce intestinal allergic symptoms similarly as foodborne illness; however, the causal relationship between gastrointestinal symptoms after $K$. septempunctata infection and the allergic response has not yet been established. However, our findings clearly demonstrated that the induction of the early stage of inflammatory response after $K$. septempunctata infection is mediated by PAMP recognition through binding between Mincle on intestinal cells and glycoconjugates on spores. Our findings highlight the importance of Mincle in triggering the inflammatory response of TNF- $\alpha$ secretion following the exposure of HT29 cells to KsAg. Although our finding is not sufficient to elucidate the complete pathogenic mechanism of Kudoa infection, this study has great significance in revealing an early inflammatory immune mechanism of food poisoning caused by the emerging infectious parasite $K$. septempunctata.

\section{MATERIALS AND METHODS}

Detection of $K$. septempunctata spores in olive flounder To identify K. septempunctata-infected olive flounder, rapid screening test (Kudoa Rapido A kit, Solforto Co., Ltd., Korea) and conventional PCR were used (Supplementary Table 1).

\section{Recovery of $K$. septempunctata from olive flounder, and viability of Kudoa spore}

Fish muscle was minced in phosphate-buffered saline (PBS) and centrifuged at $3000 \mathrm{rpm}$ for $10 \mathrm{~min}$, and the pellet was re-suspended in PBS and then placed in $10 \% / 30 \%$ Percoll gradient solution (GE Healthcare, Piscataway, NJ) in a 15-ml conical tube. After centrifugation at $3000 \mathrm{rpm}$ for $30 \mathrm{~min}$, the viability of spores in the pellet was confirmed by staining with $15 \mathrm{mM}$ propidium iodide (Sigma-Aldrich, St. Louis, MO) and 
$0.2 \% \mathrm{SYTO}^{\mathbb{R}} 9$ (Thermo Fisher Scientific, MA) for $20 \mathrm{~min}$ at RT.

\section{Genotyping of $K$. septempunctata ST3 isolates}

Conventional PCR was performed for genotyping the ST3 gene of $K$. septempunctata. The sequences of PCR products were compared with those of the $\mathrm{Rnl}$ and Cox 1 regions of a $\mathrm{K}$. septempunctata ST3 isolate (LC014799, AB915832).

\section{Preparation of the $K$. septempunctata antigen (KsAg)}

Isolated Kudoa spores were re-suspended in distilled PBS at a concentration of $5 \times 10^{7}$ spores $/ \mathrm{ml}$ and sonicated using an ultrasonic cell disruptor (Sonics Vibra Cell VCX130, Branson, $\mathrm{MO}$ ). The soluble extract (KsAg) was filtered through a 0.22$\mu \mathrm{m}$ syringe filter (Millipore, Sydney), and the concentration was quantified by BCA assay (Thermo Scientific).

\section{Cell stimulation using KsAg or live Kudoa spores}

We purchased HT29 cells from the Korean Cell Line Bank (Seoul, Korea) and cultured the cells in complete Dulbecco's modified Eagle's medium containing 10\% foetal bovine serum (WELGENE Inc.). In total, $2 \times 10^{5}$ cells/well were treated with $50 \mu \mathrm{g} / \mathrm{ml} \mathrm{KsAg}$ for $24 \mathrm{~h}$. For cell stimulation using Kudoa spores, $1 \times 10^{4}$ cells/well were treated with Kudoa spores at an $\mathrm{MOl}$ of 2, 5, or 10 for $24 \mathrm{~h}$.

\section{Attachment of Kudoa spores to HT29 cells}

For spore staining, after the PKH67 solution and spores were mixed for 10 min at RT, PKH67-labelled Kudoa spores were co-cultured with HT29 cells in 10\% FBS/DMEM at an MOI of 5 for $4 \mathrm{~h}$, and then the unbound or weakly bound Kudoa spores were washed out with PBS. Following final washing, the attached Kudoa spores were observed using fluorescent microscopy (inverted microscope [Olympus, CKX41]).

\section{qRT-PCR}

CDNA samples of HT29 cells were subjected to real-time PCR analyses using SYBR Green PCR Master Mix (TOPreal ${ }^{\text {TM }}$ qPCR 2X PreMix, Enzynomics, Daejeon, Korea). Glyceraldehyde 3phosphate dehydrogenase gene expression was evaluated in each sample as an internal control. Supplementary Table 1 shows the primer sequences. Real-time PCR analysis was performed for target genes using the CFX96 RealTime PCR Detection System (Bio-Rad, CA) and SYBR Green I detection dye. The data were presented as the expression ratio (fold change) versus the control.

\section{Cytokine array}

To investigate the cytokine profile after KsAg stimulation, HT29 cells $\left(4 \times 10^{5}\right.$ cells/well $)$ were seeded in a six-well culture plate and incubated with $50 \mu \mathrm{g} / \mathrm{ml} \mathrm{KsAg}$ for $24 \mathrm{~h}$. The culture supernatant was collected and analysed for cytokine profiles using a Human Cytokine Array C1 kit (RayBiotech, Norcross, GA).

\section{Western blotting}

After $2 \times 10^{5}$ HT29 cells were cultured with $50 \mu \mathrm{g} / \mathrm{ml} \mathrm{KsAg}$ for $24 \mathrm{~h}$, the extracted total proteins were separated using SDS-PAGE and transferred to an ImmunBlot PVDF membrane (Bio-Rad). Target antibodies and secondary antibodies were purchased from Santa Cruz Biotechnology (anti-NF-kB, antiphospho-NF-אB [Ser 311], anti- $\beta$-actin, and anti-rabbit IgG- or anti-mouse IgG-peroxidase conjugate).

\section{Immunofluorescence and lectin binding}

In total, $1 \times 10^{5}$ live Kudoa spores were seeded in a 96-well plate and fixed in $2 \%$ paraformaldehyde for $20 \mathrm{~min}$ at RT. Spores were permeabilised using $0.5 \%$ Triton X-100 for $30 \mathrm{~min}$, washed and directly stained with FITC-conjugated Bandeiraea simplicifolia agglutinin (BSL-I, Sigma-Aldrich), FITC-conjugated concanavalin A (ConA, Sigma-Aldrich), FITC-conjugated wheat germ agglutinin (WGA, Sigma-Aldrich) and FITC-conjugated Ulex europaeus agglutinin (UEA-I, Sigma-Aldrich) at $10 \mu \mathrm{g} / \mathrm{ml}$ for $1 \mathrm{~h}$ at $4^{\circ} \mathrm{C}$. The immunostained cells were observed using fluorescent microscopy (inverted microscope; CKX41, Olympus).

\section{Binding of the Mincle-Fc fusion protein to $\mathrm{KsAg}$}

$\mathrm{KsAg}(50 \mu \mathrm{g})$ was coated onto a 96 -well plate overnight at $4^{\circ} \mathrm{C}$. After blocking with $5 \%$ BSA in TBS, $5 \mu \mathrm{g} / \mathrm{ml}$ soluble Mincle-FC fusion protein (R\&D Systems) and IgG-Fc protein (R\&D Systems) were added, followed by incubation at RT for $2 \mathrm{~h}$. As a positive control, trehalose-6, 6'-dimycolate (TDM, $7.5 \mu \mathrm{g}$, SigmaAldrich) was used and alkaline phosphatase-conjugated goat anti-hFc antibody (Agrisera Antibodies) was used as the secondary antibody. After development with $p$-nitrophenyl phosphate (Sigma-Aldrich), optical densities were measured at $405 \mathrm{~nm}$.

\section{Immunostaining for Mincle expression}

HT29 cells $\left(5 \times 10^{4} /\right.$ well $)$ were incubated with $50 \mu \mathrm{g} / \mathrm{ml} \mathrm{KsAg}$ or $20 \mu \mathrm{g} / \mathrm{ml}$ TDM for $24 \mathrm{~h}$. Immunostaining was performed with an anti-CLEC4E antibody (Santa Cruz) and anti-mouse IgG Alexa $546^{\circledR}$ (Invitrogen), and the results were observed using fluorescent microscopy (Leica DMI6000B).

\section{NF-кB-inducible SEAP reporter gene assay}

HEK-Blue ${ }^{T M}$ hMincle cells (Invivogen, San Diego, CA), which are HEK 293 cells expressing human Mincle and an SEAP reporter gene, and HEK-Blue Null cells were used for the SEAP reporter gene assay. Overall, $180 \mu$ l of cell suspensions $(2.8 \times$ $10^{5}$ cells $/ \mathrm{ml}$ ), HEK-Blue hMincle and HEK-Blue Null cells and $20 \mu \mathrm{l}$ of $\mathrm{KsAg}(200 \mu \mathrm{g} / \mathrm{ml})$ were cultured in a 96-well plate for $18 \mathrm{~h}$ at $37^{\circ} \mathrm{C}$. The increase in SEAP activity was measured using a microplate reader (at $650 \mathrm{~nm}$ ).

\section{Statistical analysis}

All statistical analyses were performed using GraphPad Prism 5 software (GraphPad, La Jolla, CA, USA). Data are presented as the mean \pm SD of three independent experiments. Analyses 
were performed using Student's t-test and one-way analysis of variance followed by Newman-Keuls post-hoc test to assess the differences between the experimental groups. $\mathrm{P}<0.05$ was considered statistically significant.

\section{ACKNOWLEDGEMENTS}

This work was supported by the Research Program funded by the Korea Centers for Disease Control and Prevention (2017E54001-00). This work was supported by the Korea Association of Health Promotion Fund (Grant no. 2018-01).

\section{CONFLICTS OF INTEREST}

The authors have no conflicting interests.

\section{REFERENCES}

1. Matsukane $Y$, Sato H, Tanaka S, Kamata $Y$ and SugitaKonishi Y (2010) Kudoa septempunctata n. sp. (Myxosporea: Multivalvulida) from an aquacultured olive flounder (Paralichthys olivaceus) imported from Korea. Parasitol Res 107, 865-872

2. Kawai T, Sekizuka T, Yahata Y et al (2012) Identification of Kudoa septempunctata as the causative agent of novel food poisoning outbreaks in Japan by consumption of Paralichthys olivaceus in raw fish. Clin Infect Dis 54, 1046-1052

3. Harada T, Kawai T, Jinnai M, Ohnishi T, Sugita-Konishi $Y$ and Kumeda Y (2012) Detection of Kudoa septempunctata $18 S$ ribosomal DNA in patient faecal samples from novel food-borne outbreaks caused by consumption of raw olive flounder (Paralichthys olivaceus). J Clin Microbiol 50, 2964 2968

4. Iwashita Y, Kamijo Y, Nakahashi S et al (2013) Food poisoning associated with Kudoa septempunctata. J Emerg Med 44, 943-945

5. Ahn M, Woo H, Kang B, Jang $Y$ and Shin T (2015) Effect of oral administration of Kudoa septempunctata genotype ST3 in adult BALB/C mice. Parasite 22, 35

6. Jang $Y$, Ahn M, Bang H and Kang B (2016) Effects of Kudoa septempunctata genotype ST3 isolate from Korea on ddY suckling mice. Parasite 23, 18

7. Ohnishi T, Kikuchi Y, Furusawa H, Kamata $Y$ and SugitaKonishi Y (2013) Kudoa septempunctata invasion increases the permeability of human intestinal epithelial monolayer. Foodborne Pathog Dis 10, 137-142

8. Ahn M, Ko HJ, Kim J, Jang Y and Shin T (2018) Evaluation of the inflammatory response to Kudoa septempunctata genotype ST3 isolated from olive flounder (Paralichthys olivaceus) in Caco-2 cells. Parasite 25, 12

9. Ohnishi T, Oyama R, Furusawa $H$, Ohba N, Kamata $Y$ and Sugita-Konishi Y (2013) Kudoa septempunctata was recognised by Toll-like receptor 2 produced by a RAW 264 macrophage-like cell line. Food Addit Contam Part A Chem Anal Control Expo Risk Assess 30, 1365-1369

10. Kang J, Park C, Jang Y, Ahn M and Shin T (2016) Lectin histochemistry of Kudoa septempunctata genotype ST3-infected muscle of olive flounder (Paralichthys olivaceus). Parasite 23, 21

11. Jung KS, Ahn MJ, Lee YD, Go GM and Shin TK (2002) Histochemistry of six lectins in the tissues of the flat fish Paralichthys olivaceus. J Vet Sci 3, 293-302.

12. te Velde AA (2017) The C-Type Lectin Mincle: Clues for a Role in Crohn's Disease Adjuvant Reaction. Front Immunol 8, 1304

13. Meyer-Wentrup F, Cambi A, Figdor CG, and Adema GJ (2007) Detection of Fungi by Mannose-based Recognition Receptors. In Immunology of Fungal Infections, 293-307. Springer, Netherland, Dordrecht

14. Park JH (2017) Analysis of Kudoa septempunctata as a cause of foodborne illness and its associated differential diagnosis. Epidemiol Health 39, e2017037

15. Lee SU (2017) Analysis of Kudoa septempunctata as a cause of foodborne illness and its associated differential diagnosis. Epidemiol Health 39, e2017037r

16. Chung YB and Bae JM (2017) Is there evidence that Kudoa septempunctata can cause an outbreak of acute food poisoning? Epidemiol Health 39, e2017004

17. Lee RT, Hsu TL, Huang SK, Hsieh SL, Wong CH and Lee YC (2010) Survey of immune-related, mannose/fucosebinding C-type lectin receptors reveals widely divergent sugar-binding specificities. Glycobiology 21, 512-520

18. Schick J, Etschel P, Bailo R et al (2017) Toll-like receptor 2 and Mincle cooperatively sense corynebacterial cell wall glycolipids. Infect Immun 85, e00075-17

19. Kostarnoy AV, Gancheva PG, Lepenies B et al. (2017) Receptor Mincle promotes skin allergies and is capable of recognizing cholesterol sulphate. Proc Natl Acad Sci U S A 114, E2758-2765

20. de Velasco GM, Rodero M and Cuéllar C (2003) Specific IgE induced by Kudoa sp.(Myxosporea: multivalvulida) antigens in BALB/C mice. Parasite 10, 379-381

21. de Velasco GM, Rodero $M$, Cuéllar $C$, Chivato $T$, Mateos JM and Laguna R (2008) Skin prick test of Kudoa sp. antigens in patients with gastrointestinal and/or allergic symptoms related to fish ingestion. Parasitol Res 103, 713715

22. Ohnishi T, Kubo A, Yoshinari T and Watanabe MA (2018) Kudoa septempunctata antigen induces production of IgE in BALB/c mice. Parasitol Res 117, 303-306 